\title{
FORMATION OF COMMUNICATIVE AND SPEAKING COMPETENCE OF SOCIAL WORKERS IN THE PROCESS OF PROFESSIONAL TRAINING
}

\author{
Liudmyla Berezovska \\ PhD in Education, Associate Professor, Precarpathian National University, \\ Ivano-Frankivsk, Ukraine
}

DOI: https://doi.org/10.31435/rsglobal_ws/31032020/6986

\section{ARTICLE INFO}

Received: 21 January 2020

Accepted: 19 March 2020

Published: 31 March 2020

\section{KEYWORDS}

levels of formation, communication and speaking competence, experimental methodology, training of social workers, research results.

\begin{abstract}
The article analyses the levels of communication skills of future social workers at the final stage of the research. It is stated that implementation of communication and speaking training is conditioned by the necessity of forming a competent specialist who has deep theoretical knowledge, communication skills necessary for establishing constructive interpersonal interaction and providing assistance to different groups of clients, and operates innovative technologies methods of assistance. It is possible to achieve a high level of professional competence during training, through a specially organized educational process aimed at the development of professional, communication and speaking skills that form the basis of future work of a social worker. The results of the study showed positive changes in the students of the experimental group, which made it possible to conclude on the efficiency of the proposed experimental method of forming the communicative and speaking competence of future social workers in the process of professional training.
\end{abstract}

Citation: Liudmyla Berezovska. (2020) Formation of Communicative and Speaking Competence of Social Workers in the Process of Professional Training. World Science. 3(55), Vol.3. doi: 10.31435/rsglobal_ws/31032020/6986

Copyright: (C) 2020 Liudmyla Berezovska. This is an open-access article distributed under the terms of the Creative Commons Attribution License (CC BY). The use, distribution or reproduction in other forums is permitted, provided the original author(s) or licensor are credited and that the original publication in this journal is cited, in accordance with accepted academic practice. No use, distribution or reproduction is permitted which does not comply with these terms.

Introduction. The relevance of the study preparation of students - future social workers to the implementation of communicative and speaking activity emerges from the need of formation of a competent specialist with deep theoretical knowledge, innovative technologies and techniques to aid communicative skills necessary for establishing constructive interpersonal interaction on all levels of administration, skilfully solves complex professional tasks that require critical thinking and thorough analysis of the situation, responsible for decision making and to assist different groups of customers, recognises the importance of the profession of a social worker. It is possible to achieve a high level of professional competence during training, perhaps due to the specially organized educational process aimed at the development of professional, communicative and linguistic skills that form the basis of future activities of the social worker.

Theoretical aspects of the problem of formation of culture of communication and communicative skills are covered in the works by N. Babych, R. Vainola, N. Volkova, D. Hodlevska, Yu. Yemelianov, M. Kahan, O. Kaniuk, O. Karpenko, O. Korniiaka, M. Pentyliuk, V. Polishchuk and others. Despite the extensive research on the training of future social workers, the problem of communicative competence has not been systematically covered.

The purpose of the article is to substantiate and analyse the results of diagnostics of levels of communication and speaking competence of future social workers at the final stage of the research.

The complexity of diagnosing communicative and speaking competence (CSC) was both its criterion definition and the selection of tools that should describe both understanding and actions of 
the subjects of vocational training. Criteria and indicators are important elements of the evaluation of the formation of CSC's of a future social worker.

A criterion is an important attribute that characterizes the qualitative aspects of an object, subject, phenomenon, and allows somebody to judge its status, level of development and functioning. Each criterion is revealed through a system of indicators that characterize it. An indicator is what can be used to judge the development and progress of something [1]; as testimony, evidence, a sign of anything [2].

In determining the criteria apparatus, the basic requirements for the criteria were taken into account. The criteria should be disclosed through a series of indicators that meet them. To reflect the basic laws of formation of communicative and speaking competence. To cover all kinds of communication activities of a social worker. To reflect the dynamics of formation of communicative and speaking competence of future social workers. According to the criteria the connections between all components of the system of formation of communicative and speaking competence are established [3].

Indicators of the cognitive-speaking criterion are: awareness of the concepts: «communication», «discourse», «communication and speaking activity»; awareness of the concept of «social worker - the subject of communication, speech, professional activity»; awareness of the concepts of «competence», «competency»; awareness of the concepts of «speaking competence», «communicative competence», "communicative and speaking competence»; awareness of the concepts of «communicative-speaking support of a social worker's professional activity».

The communicative-effective criterion included the following indicators: ability to organize initiative-discourse communication with the client; ability to use verbal and non-verbal means of language expressiveness and formulas of speaking etiquette; ability to constructively resolve conflict situations, predict partner behaviour.

Indicators of the evaluation and reflection criterion are defined as follows: ability to carry out self-analysis of one's communicative and speaking actions in communication with a partner; ability of effective speech self-presentation «I am a social worker» (self-esteem); ability to adequately evaluate the communicative and speaking activities of future social workers (mutual evaluation).

Diagnostic tools were selected for each criterion and indicator and the levels of communication competence were established: high, sufficient, satisfactory and low.

Because of the ascertaining stage of the research, the levels of communication and speaking competence formation of future social workers in higher education institutions did not meet the requirements for professional training of future social workers.

Starting the formulaic stage of the experiment, a model of training future social workers for organizing communication and speaking activities in higher education institutions was developed.

In dictionary sources, the term «model» is defined as «reduced or increased reproduction of anything; a scheme for explaining an object, a phenomenon, a process in nature and society» [4].

The developed model embraces the goal, methodological approaches (system-holistic, communicative-activity, competence), stages of formation of communicative-speaking competence (information enriching, communicative-activity, productive-creative, evaluative-reflective), means, forms, methods of work at each stage. Pedagogical conditions (integration of linguistic and professional disciplines in the process of formation of communicative and speaking competence of future social workers in higher education institutions; positive motivation of future social workers to form their professional, communicative and speaking activities; aimed at the development of professionally directed speech), criteria (cognitive-speech, communicative-effective, evaluativereflective) and levels (high, sufficient, satisfactory, low).

At each stage of the formation of communicative and speaking competence of future social workers in the process of professional training through various forms, methods and techniques, educational activities were carried out.

Research results. To check the efficiency of the formative stage of the experimental study, a control testing was performed. Its tasks were identical to those performed by the students - future social workers at the ascertaining stage of the study.

The purpose of the first control testing was to determine the levels of communication skills of students of the experimental and control groups according to the proficiency criterion (Table 1). 
Table 1. Comparative data of the levels of communicative and speaking competence formation of future social workers of experimental and control groups by knowledge and speech criterion

\begin{tabular}{|c|c|c|c|c|c|c|c|c|}
\hline \multirow[t]{2}{*}{ Groups } & \multirow{2}{*}{ Levels } & \multirow{2}{*}{ Stages } & \multicolumn{5}{|c|}{ Indicators } & \multirow[b]{2}{*}{$\chi$} \\
\hline & & & $\mathrm{P} 1$ & $\mathrm{P} 2$ & P3 & $\mathrm{P} 4$ & P5 & \\
\hline \multirow{8}{*}{ EG } & \multirow{2}{*}{ High } & AS & 9,7 & 8,6 & 10,1 & 7,3 & 6,2 & 8,38 \\
\hline & & FS & 22,3 & 21,8 & 24,3 & 18,3 & 15,7 & 20,48 \\
\hline & \multirow{2}{*}{ Sufficient } & AS & 16,4 & 10,1 & 17,6 & 11,3 & 12,4 & 13,56 \\
\hline & & FS & 39,5 & 37,3 & 33,8 & 32,4 & 26,8 & 33,96 \\
\hline & \multirow{2}{*}{ Satisfactory } & AS & 28,7 & 24,6 & 31,3 & 25,2 & 27,7 & 27,5 \\
\hline & & FS & 20,6 & 22,9 & 27,4 & 29,7 & 38,3 & 27,78 \\
\hline & \multirow{2}{*}{ Low } & AS & 45,2 & 56,7 & 41,0 & 56,2 & 53,7 & 50,56 \\
\hline & & FS & 17,6 & 18,0 & 14,5 & 19,6 & 19,2 & 17,78 \\
\hline \multirow{8}{*}{$\mathrm{CG}$} & \multirow{2}{*}{ High } & AS & 9,1 & 8,2 & 10,4 & 7,6 & 6,4 & 8,34 \\
\hline & & FS & 14,8 & 12,1 & 15,2 & 10,4 & 9,7 & 12,44 \\
\hline & \multirow{2}{*}{ Sufficient } & AS & 17,2 & 10,4 & 17,5 & 10,9 & 12,1 & 13,62 \\
\hline & & FS & 23,9 & 15,2 & 21,6 & 17,3 & 18,6 & 19,32 \\
\hline & \multirow{2}{*}{ Satisfactory } & AS & 29,8 & 23,9 & 31,7 & 25,6 & 28,3 & 27,86 \\
\hline & & FS & 25,1 & 27,4 & 42,5 & 38,1 & 31,0 & 32,82 \\
\hline & \multirow{2}{*}{ Low } & AS & 43,9 & 57,5 & 40,4 & 55,9 & 53,2 & 50,18 \\
\hline & & FS & 36,2 & 45,3 & 20,7 & 34,2 & 40,7 & 35,42 \\
\hline
\end{tabular}

As we can see from Table 1., by indicator (P 1) - awareness of the concepts: 2 «communication», «discourse», «high-level communication and speaking activities reached» 22,3\% of students of EG (was 9,7\%) and 14,8\%-CG (9,1\%), 39,5\% of EG respondents $(16,4 \%)$ and $23,9 \%$ - of CG $(17,2 \%)$ were sufficiently present, a satisfactory level was recorded in $20,6 \%$ of EG students $(28,7 \%)$ and $25,1 \%$ - CG $(29,8 \%)$, low level was evidenced by $17,6 \%$ of EG students $(45,2 \%)$ and $36,2 \%-\mathrm{CG}(43,9 \%)$.

The results of the EG students' completion of the final tasks revealed significant changes in the responses of future social workers. Most EG students $(39,5 \%)$ showed a sufficient level. In CG of students, the indicators have changed, but not significantly, 36,2\% of CG students proved a low level.

Indicator (P2) - awareness of the concept of «social worker - the subject of communication, speaking and professional activity», the following results were obtained: $21,8 \%$ of EG students $(8,6 \%)$ and $12,1 \%$ - proved a high level. Students of CG $(8,2 \%)$, sufficient level was recorded in $37,3 \%$ of the EG respondents $(10,1 \%)$ and $15,2-\mathrm{CG}(10,4 \%)$, and $22,9 \%$ of the EG students were satisfactory $(24,6 \%)$ and $27,4 \%-\mathrm{CG}(23,9 \%), 18 \%$ of EG students $(56,7 \%)$ and $45,3 \%-\mathrm{CG}(57,5 \%)$.

Indicator (P3) - awareness of the concepts of «competence», «competency» showed that a high level reached by $24,3 \%$ of students EG (was 10,1\%) and 15,2\%-CG (was 10,4 \%), 33,8\% of EG students $(17,6 \%)$ and $21,6 \%$ of CG students $(17,5 \%)$ have mastered the satisfactory level, $27,4 \%$ of EG students and $42,5 \%$ of CG students have satisfactory levels $31,3 \%$ and $31,7 \%$, respectively). The low level was fixed in $14,5 \%$ of EG students $(41 \%)$ and 20,7 \% - CG (40,4\%).

According to the indicator (P 4$)-18,3 \%$ of students of EG $(7,3 \%)$ and $10,4 \%$ of KG (awareness of the concepts of «speaking competence», «communicative competence» «communicative and speaking competence») 7,6\%), 32,4\% of EG students (11,3\%) and 17,3\% of CG students (10,9\%) testified to a sufficient level, 29,7 \% of EG students (25,2\%) and 38,1\%-CG (25,6\%). Low level was found in 19,6\% of students of $\mathrm{EG}$ and $34,2 \%$ in $\mathrm{CG}(56,2 \%$ and $55,9 \%$ respectively).

The data obtained showed that, unlike the ascertainment stage, the majority of students $(32,4 \%)$ of EG showed a sufficient level of awareness of the concepts of «speaking competence», «communicative competence», «communicative and speaking competence». On the other hand, CG students were at satisfactory $(38,1 \%)$ and low $(34,2 \%)$ levels.

Indicator (P 5) - awareness of the concepts of «communicative and speaking support of a social worker's professional activity showed» that $15,7 \%$ of EG students $(6,2 \%)$ and $9,7 \%$ - of CG $(6,4 \%$ reached a high level), 33,8 \% of EG students $(17,6 \%)$ and $18,6 \%$ of CG students $(12,1 \%)$ were identified at a sufficient level, $38,3 \%$ of EG students $(27,7 \%)$ testified to a satisfactory level and $31 \%$ of CG $(28,3 \%)$, low was seen in 19,2\% of EG students and 40,7 \% of CG students (53,7\% and 53,2\%). 
On a whole, $20,48 \%$ of students of EG $(8,38 \%)$ and $12,44 \%$ of CG $(8,34 \%)$ reached the high level of knowledge and speech criterion of formation of communicative and speaking competence of future social workers. 33,96\% of EG students $(13,56 \%)$ and 19,32 \% of EG students $(13,62 \%)$, satisfactory level was confirmed by $27,78 \%$ of EG students $(27,5 \%)$ and $32,82 \%$ of CG $(27,86 \%)$, low was found in $17,78 \%$ of EG students $(50,56 \%)$ and $35,42 \%$ of CG students $(50,18 \%)$.

The dynamics of the levels of communication and speaking competence formation according to the cognitive and speech criterion at the ascertaining and final stages of the experiment are presented in Figure 1.1.

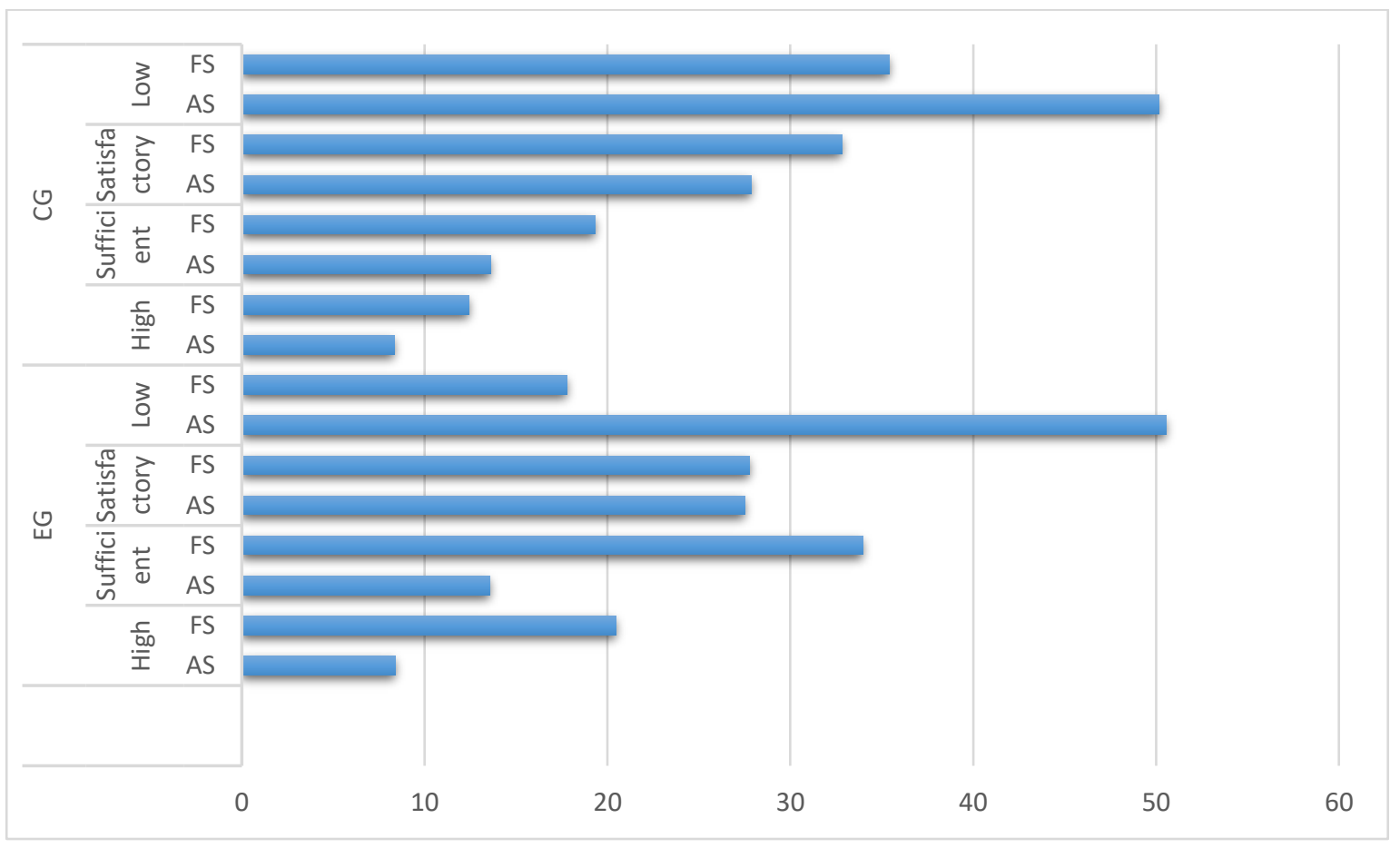

Fig. 1.1. Dynamics of levels of communication and speaking competence formation by the cognitivespeech criterion at the ascertaining and final stages of the experiment (for $\chi$ arithmetic mean, in \%)

As can be seen from Fig. 1.1. there were significant changes in the levels of communication and speaking competence formation according to the communicative-performance criterion in the experimental group compared to the control group. Thus, at a high level, the results increased by $11 \%$ in the EG and by $3 \%$ in the CG, at a sufficient level - by $20,1 \%$ in the EG and by $5,1 \%$ in the CG, at a satisfactory level the results decreased by $8,2 \%$ in CG and 1,2 \% in EG, at a low level - by 22,9\% in EG and 9,3\% in CG.

We will demonstrate comparative data of the levels of communication and speaking competence of future social workers by the communicative-effective criterion at the ascertaining and final stages of the experiment in Table 2 .

As we can see from Table 2. by indicator (P 1) - 19,6\% of EG students and 9,1\% of CG students $(7,4 \%$ and $6,8 \%)$ were able to organize initiative and dialogue communication of the communicative-effective criterion of high level of communication and speaking competence formation. A sufficient level was found in 32,8 \% of EG students and 17,4 \% of EG students $(11,6 \%$ and $6,8 \%$ respectively). At a satisfactory level were $28,4 \%$ of students of EG and $41,2 \%$ of students of CG (it was 36,5\% and 38,7\%). The low level was recorded in 19,2\% of EG students and 32,3\% of EG students (44\% and $43,9 \%$ respectively).

In contrast to the ascertainment stage, 32,8\% of EG students showed a sufficient level of formation of ability to organize initiative-dialog communication with the client, mastered the rules of conducting dialogue, etiquette forms of professional-business communication. In CG, the indicators improved, but not significantly, in particular, there were $32,3 \%$ of students at a low level, $43,9 \%$ at the ascertainment stage. Students of this level have not mastered the skills of dialogue in accordance with the tasks set, the ability to constructively converse to clarify the circumstances of the situation and to assist the client. 
Table 2. Formation levels of communication and speech competence of future social workers according to the communicative-effective criterion at the ascertaining and final stages of the experiment (in\%)

\begin{tabular}{|c|l|c|c|c|c|c|c|c|c|}
\hline \multirow{3}{*}{ Groups } & \multirow{9}{*}{ Levels } & \multicolumn{2}{|c|}{ Indicators } & \multicolumn{2}{c|}{ P2 } & \multicolumn{2}{|c|}{ P 3 } & \multicolumn{2}{|c|}{$\chi$} \\
\cline { 3 - 10 } & & AS & FS & AS & FS & AS & FS & AS & FS \\
\hline \multirow{4}{*}{ EG } & High & 7,4 & 19,6 & 8,1 & 18,3 & 6,7 & 17,3 & 7,4 & 18,4 \\
\cline { 2 - 10 } & Sufficient & 11,6 & 32,8 & 14,5 & 37,4 & 17,3 & 33,6 & 14,5 & 34,6 \\
\cline { 2 - 10 } & Satisfactory & 36,5 & 28,4 & 32,4 & 21,5 & 35,2 & 29,7 & 34,7 & 26,5 \\
\cline { 2 - 10 } & Low & 44,5 & 19,2 & 45,0 & 22,8 & 40,8 & 19,4 & 43,4 & 20,5 \\
\hline \multirow{5}{*}{ CG } & High & 6,8 & 9,1 & 7,8 & 11,2 & 7,0 & 10,3 & 7,2 & 10,2 \\
\cline { 2 - 10 } & Sufficient & 10,6 & 17,4 & 14,7 & 19,3 & 16,6 & 20,5 & 13,9 & 19,0 \\
\cline { 2 - 10 } & Satisfactory & 38,7 & 41,2 & 32,6 & 30,8 & 34,8 & 37,4 & 35,3 & 36,5 \\
\cline { 2 - 10 } & Low & 43,9 & 32,3 & 45,4 & 38,7 & 41,6 & 31,8 & 43,6 & 34,3 \\
\hline
\end{tabular}

Indicator (P 2$)-18,3 \%$ of EG students $(8,1 \%)$ and $11,2 \%$ of CG $(7,8 \%)$ were able to use verbal and non-verbal means of speech expressiveness and formulas of high etiquette of communicative speech competence, a sufficient level was found in $37,4 \%$ of EG respondents $(14,5 \%)$ and $19,3 \%$ - CG (14,7 \%), with $22,8 \%$ of future EG workers and low 38,7 \% - CG (45\% and $45,4 \%$, respectively).

The data show that the majority of EG students $(37,4 \%)$ showed a sufficient level of development of the ability to use the means of speech expression in situations of professional and business communication, to describe psychological states and emotions, unlike the students of CG, where $38,7 \%$ of the respondents remained at low level.

Indicator (P3) - «ability to constructively resolve conflict situations, predict partner behaviour» showed that $17,3 \%$ of students - future social workers of EG $(6,7 \%)$ and $10,3 \% \mathrm{CG}$ (7\%), attained a high level of communicative speaking competence formation $33,6 \%$ of students $(17,3 \%)$ and $20,5 \%$ - CG $(16,6 \%)$, a sufficient level was confirmed by $29,7 \%$ of EG students and $37,4 \%$ of CG $(35,2 \%$ and $34,8 \%$, respectively). Low levels were found in $19,4 \%$ of students of EG $(40,8 \%)$, and $31,8 \%-\mathrm{CG}(41,6 \%)$.

In general, $18,4 \%$ of students - future social workers $(6,7 \%)$ and $10,2 \%-\mathrm{CG}(7,2 \%)$, reached a sufficient level of 34,6\% of EG students $(14,5 \%)$ and $19 \%-\mathrm{CG}(13,9 \%)$, satisfactory level was confirmed by $26,5 \%$ of EG students $(34,7 \%)$ and $36,5 \%-$ CG $(35,3 \%)$. Low was in $20,5 \%$ of EG students $(43,4 \%)$ and $34,3 \%$ of CG students $(43,6 \%)$.

The dynamics of the levels of formation of communicative and speaking competence of future social workers by the communicative-effective criterion at the ascertaining and final stages of the experiment are shown in Fig. 2.1.

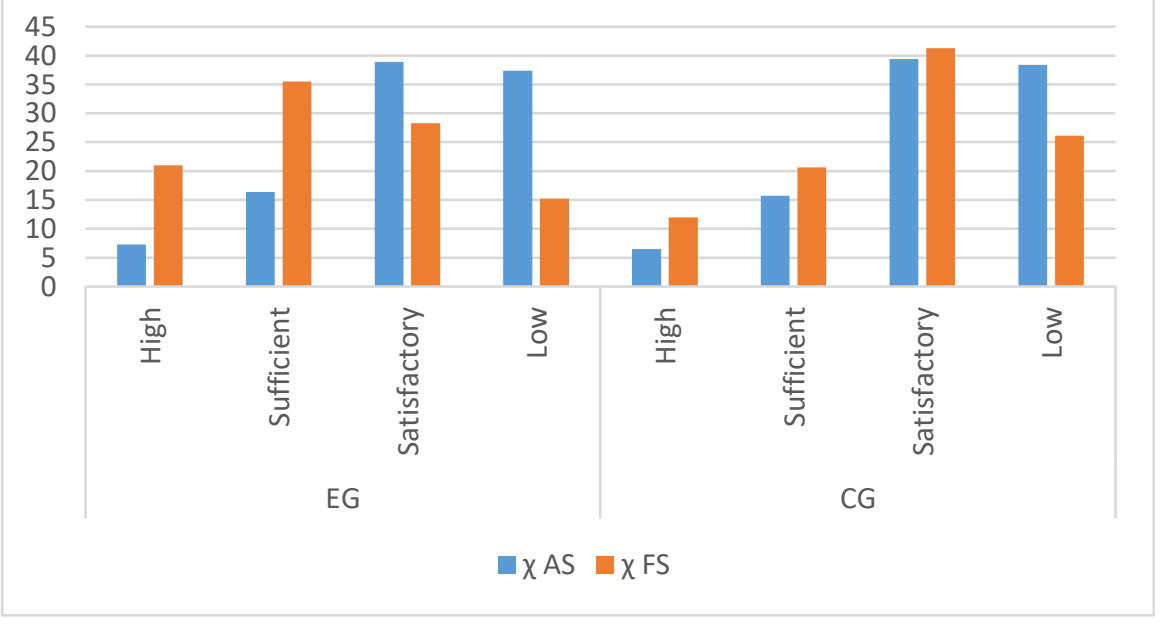

Fig. 2.1. Dynamics of levels of communicative and speaking competence formation according to the communicative-active criterion at the ascertaining and final stages of the experiment (for $\chi$ arithmetic mean, in\%) 
As can be seen from Fig.2.1. significant changes in the levels of communication and speaking competence formation according to the communicative-performance criterion occurred in the experimental group students compared to those of control group students. Thus, at a high level, the results increased by $11 \%$ in the EG and by $3 \%$ in the CG, at a sufficient level - by $20,1 \%$ in the EG and by $5,1 \%$ in the CG, at a satisfactory level the results decreased by $8,2 \%$ in CG and $1,2 \%$ in EG, at a low level - by $22,9 \%$ in EG and 9,3\% in CG.

Comparative data of the levels of communication and speaking competence formation at the ascertaining and final stages of the experiment are given in Table 3.

Table 3. The results of the formation of levels of communication and speech competence of future social workers for evaluation and reflection criteria on ascertaining and final stages of the experiment (in\%)

\begin{tabular}{|c|c|c|c|c|c|c|c|c|c|}
\hline \multirow{3}{*}{ Groups } & \multirow{3}{*}{ Levels } & \multicolumn{6}{|c|}{ Indicators } & \multirow{2}{*}{\multicolumn{2}{|c|}{$\chi$}} \\
\hline & & \multicolumn{2}{|c|}{ P 1} & \multicolumn{2}{|c|}{ P 2} & \multicolumn{2}{|c|}{ P 3} & & \\
\hline & & AS & FS & AS & FS & $\mathrm{AS}$ & FS & AS & FS \\
\hline \multirow{4}{*}{ EG } & High & 5,3 & 19,7 & 7,9 & 22,4 & 8,6 & 21,0 & 7,3 & 21,0 \\
\hline & Sufficient & 11,5 & 32,4 & 14,2 & 37,5 & 23,6 & 36,7 & 16,4 & 35,5 \\
\hline & Satisfactory & 39,2 & 30,6 & 36,4 & 24,3 & 41,0 & 29,9 & 38,9 & 28,3 \\
\hline & Low & 44,0 & 17,3 & 41,5 & 15,8 & 26,8 & 12,4 & 37,4 & 15,2 \\
\hline \multirow{4}{*}{ CG } & High & 4,6 & 9,6 & 7,2 & 12,3 & 7,7 & 14,2 & 6,5 & 12,0 \\
\hline & Sufficient & 10,8 & 16,2 & 13,6 & 19,4 & 22,8 & 26,3 & 15,7 & 20,6 \\
\hline & Satisfactory & 38,7 & 45,4 & 34,8 & 38,8 & 44,6 & 39,7 & 39,4 & 41,3 \\
\hline & Low & 45,9 & 28,8 & 44,4 & 29,5 & 24,9 & 19,8 & 38,4 & 26,1 \\
\hline
\end{tabular}

As can be seen from Table 3. by indicator (P 1) - the ability to perform self-analysis of communicative and speaking actions in communication with a partner at the final stage of the study in the experimental group, there were positive changes. $19,7 \%$ of EG students $(5,3 \%)$ and $9,6 \%$ of CG students $(4,6 \%)$ reached a high level, $32,4 \%$ of EG students $(11,5 \%)$ were at a sufficient level and $16,2 \%$ - CG (10,8 \%), satisfactory level was found by 30,6\% of students of EG $(39,2 \%)$ and $45,4 \%$ - CG $(38,7 \%)$, low level was confirmed by $17,3 \%$ of EG students $(44 \%)$ and $28,8 \%$ of future CG social workers $(45,9 \%)$.

Indicator (P 2) - «ability to speak effectively self-presentation «I am a social worker» (selfestimation)» of the evaluative-reflective criterion revealed the following results: high level was demonstrated by $22,4 \%$ of students - future social workers of EG $(7,9 \%)$ and $12,3 \%$ - CG $(7,2 \%)$, sufficient level was found by $37,5 \%$ of students of EG (14,2\%) and 19,4\% - CG (13,6\%), was at a satisfactory $24,3 \%$ of EG students and $38,8 \%$ of CG $(36,4 \%$ and $34,8 \%)$, low level was evidenced by $15,8 \%$ of EG students (41,5\%), and 29,5\% - CG (was 44,4\%).

Indicator (P 3) - the ability to adequately assess the communication and speaking activity of future social workers (mutual evaluation) at a high level revealed $21 \%$ of students of EG $(8,6 \%)$ and $14,2 \%$ - CG (7,7\%). 36,7 \% of EG students and 26,3\% of EG students (at 23,6\% and 22,8\% respectively) were at a sufficient level, $29,9 \%$ of EG students (41\%) and 39,7\% had a satisfactory level- CG (44,6\%), low level was noticed in $12,4 \%$ of EG students $(26,8 \%)$ and $19,8 \%$ of future CG social workers $(24,9 \%)$.

In general, $21 \%$ of EG students $(7,3 \%)$ and $12 \%-\mathrm{CG}(6,5 \%)$ demonstrated a high level of communicative and speaking competence according to the criterion of communication and speaking competence formation, and 35,5\% of EG students testified to a sufficient level. $16.4 \%$ and 20,6\% CG $(15,7 \%), 28,3 \%$ of EG students $(38,9 \%)$ and $41,3 \%$ - CG $(39,4 \%), 15,2 \%$ of EG students and $26,1 \%$ of future CG social workers were recorded at a low level (37,4\% and $38,4 \%$ respectively).

The dynamics of the levels of communication and speaking competence formation of future social workers according to the evaluative-reflective criterion at the ascertaining and final stages of the experiment are presented in Fig. 3.1.

As can be seen from Fig. 3.1.as for the high-level of evaluative-reflective criterion, the results increased by $13,7 \%$ in the EG and 5,5\% in the CG, at a sufficient level by $19,1 \%$ in the EG and $4,9 \%$ in the CG. Satisfactory indicators decreased by $10,6 \%$ in the EG students, increased by $1,9 \%$ in those of the CG, decreased by $22,2 \%$ in the EG and $12,3 \%$ in the CG. 


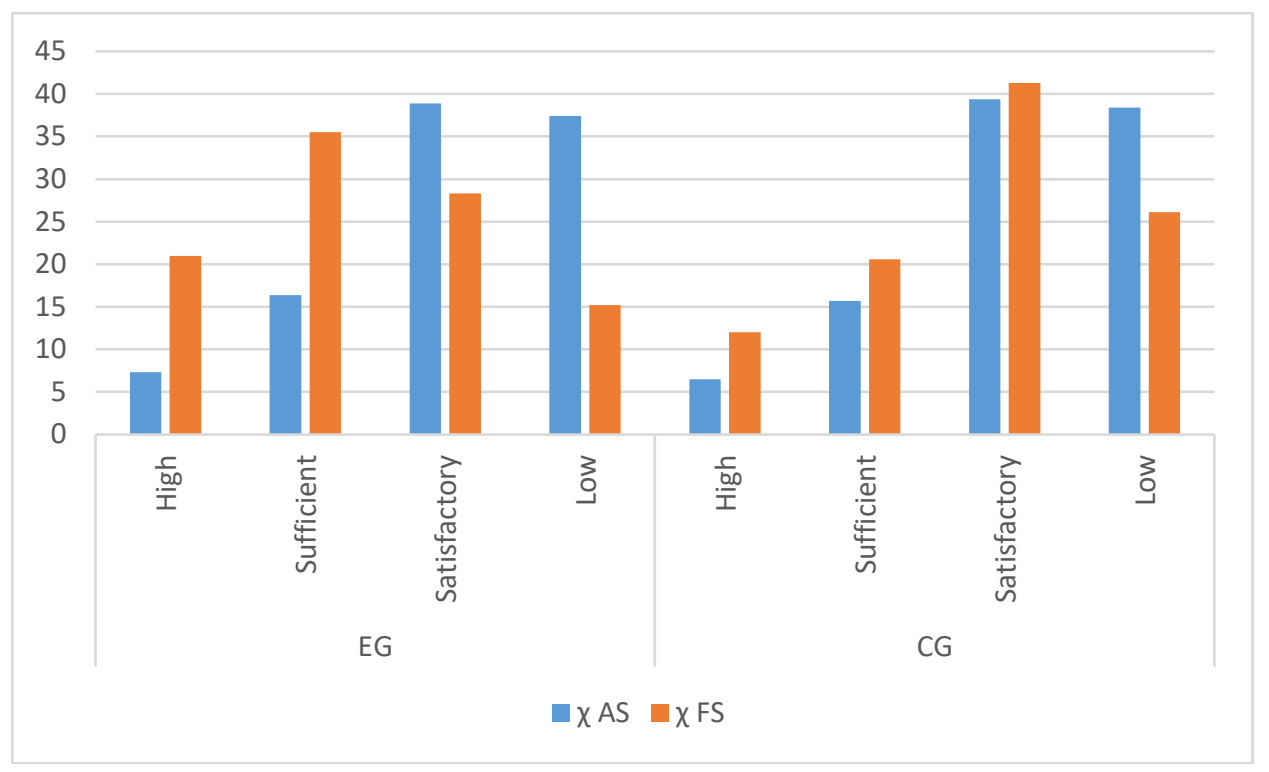

Fig.3.1. Dynamics of levels of communication and speech competence formation according to the evaluative-reflective criterion at the ascertaining and final stages of the experiment (for $\chi$ arithmetic mean, in\%)

Conclusions. Comparative results of levels of communication and speaking competence of future social workers at the final stage of the study showed positive changes in the students of the experimental group. This made it possible to conclude the need for purposeful systematic work with students in mastering the necessary professional knowledge and practical skills that form the basis of communication and speaking competence. The results of the study confirmed the efficiency of the suggested experimental method of forming the communicative and speaking competence of future social workers in the process of professional training.

\section{REFERENCES}

1. Shvedova, N. Ju. (1986). Slovar' russkogo jazika: Okolo 57000 slov. [Russian Dictionary: About 57,000 words] Moscow. (rus).

2. Busel, V. T. (2005). Velykyi tlumachnyi slovnyk suchasnoi ukrainskoi movy [Great explanatory dictionary of modern Ukrainian language]. Kyiv, Irpin: Perun [ukr].

3. Isaev, I. F. (1997). Shkola kak pedagogicheskaja sistema: osnovy upravlenija [School as a pedagogical system: basics of management]. Belgorod (rus).

4. Skopnenko, O. I., Tsymbaliuk T. V., (2006). Suchasnyi slovnyk inshomovnykh sliv [Modern dictionary of foreign words: about 20 thousand words and phrases]. Kyiv, Dovira. [ukr]. 